\title{
Mothers' Knowledge of Immunization In Akure North Local Government Area of Ondo State, Nigeria.
}

\author{
Rosena Olubanke Oluwafemi ${ }^{1}$,Olushola B Fasubaa, ${ }^{2}$ Osayame Ekhaguere, ${ }^{3}$ \\ Butali Azeez. ${ }^{4}$ \\ ${ }^{I}$ Paediatrics Department, Mother And Child Hospital, Akure, Ondo State, Nigeria. \\ ${ }^{2}$ Department Of Obstetrics And Gynaecology, College Of Health Sciences, Obafemi Awolowo University, \\ Ile-Ife, Nigeria. \\ ${ }^{3}$ Division Of Neonatology, The Children's Hospital Of Philadelphia, USA \\ ${ }^{4}$ Department Of Oral Pathology, Radiology And Medicine, College Of Dentistry, University Of Iowa, USA.
}

\begin{abstract}
:
Background: Vaccine-Preventable Diseases (Vpds) Are Quite Common In Poorly Developed Countries Leading To A High Under 5 Morbidity And Mortality. In These Resource-Poor Settings, Immunization Has Been Shown To Prevent About Three Million Child Deaths Annually. Also Immunization Health Literacy Of A Parent Is Essential To Achieving And Maintaining The Gains Derived From Immunization Programs. However, Studies Examining The Degree Of Maternal Immunization Health Literacy In Ondo State, Nigeria Are Lacking.

Aims: To Assess Mothers' Knowledge Of The National Programme On Immunization (NPI) Schedule In Akure North Local Government Area Of Ondo State.

Method: An Interviewer-Administered Questionnaire Was Used To Get Information From Mothers Who Have At Least One Child Aged 1 To 5 Years In The Communities. This Was Done To Assess Their Knowledge On Infant Immunization. Survey Participants Were Selected Using A Systematic Random Sampling Method. Mothers' Knowledge Was Assessed By Their Ability To List The Vaccines, Recall The Immunization Schedule, List The Diseases Vaccines Prevent, Side Effects Of The Vaccines And Remedies To Ameliorate Side Effects.

Results: The Total Number Of Mother-Child Pairs Recruited For This Study Was 560. Altogether, 248 (44.3\%) Of The Respondents Could Mention At Least 5 Vaccines And More Than 90\% Of The Mothers Knew And Kept The Immunization Schedule. Fever Was The Most Common Side Effect Reported And Majority Of The Mothers Sought Hospital Treatment After A Cold Bath For The Baby.

Conclusion: Although The Knowledge Of Immunization Of Mothers In The Akure North Local Government Is High, Significant Differences Exist Between Communities. Interventions To Improve And Sustain Immunization Health Literacy Should Be Instituted.
\end{abstract}

Keywords: Immunization, Knowledge, Ondo State, Nigeria.

\section{Introduction}

Vaccine-preventable diseases (VPDs) are the major causes of under 5 morbidity and mortality in the resourcepoor and developing countries. Immunization has been proven to be a cost-effective public health intervention to reduce the morbidity, mortality and the disabilities associated with these VPDs. ${ }^{[1]}$ Immunization

has also been shown to prevent about three million child deaths annually with additional 2 million deaths likely to be prevented with improvement in coverage. ${ }^{[1]}$

Immunization is the process of inducing immunologic defence against infectious organisms without significant risk to the recipient. ${ }^{[2]}$ Immunization can prevent infectious diseases in an individual, restrict the spread of diseases in the community (by herd immunity) and may ultimately eradicate the disease. ${ }^{[2]}$

Nigeria, like many countries in the African region, is making efforts to reduce the disease burden from vaccine-preventable diseases (VPDs) by strengthening the general health and routine immunizations systems and services. Strategies include immunization education at antenatal clinics, post-natal clinics, on television and radio in particular. ${ }^{[3]}$ Good parental knowledge and practice regarding immunization is needed to reduce the incidence of infectious diseases. ${ }^{[4]}$ Immunization is considered to be second to water in order of importance in the control of infectious diseases. ${ }^{[5]}$ Parental knowledge regarding vaccination is related to appropriate sources of information, the number of sources and the way that vaccine information is received by parents. Knowledge is also related to sources of information provided by maternity clinics, the media, literature, and the internet which cover vaccination benefits and the risks of vaccine-preventable diseases. ${ }^{[6]}$ Many studies have also shown that parents' knowledge regarding child immunization varies according to level of exposure, level of education, interaction with the family physician and other medical staff. $[7],[8],[9],[10]$

There is presently a dearth of literature on the current level of awareness and knowledge of mothers in rural Ondo State, therefore, the current study is aimed at assessing the knowledge of mothers in Akure North 
local Government Area of Ondo State. Information obtained in these communities may be representative of similar rural communities in Ondo and its environs and thus can inform strategies for improvement and effective immunization programs.

\subsection{Study Setting:}

\section{Subjects And Methods}

The study was community-based, descriptive and cross-sectional. It was conducted in the Akure North Local Government Area (LGA) of Ondo State in January, 2016. Ondo State is a petroleum oil producing state with a long coastal line, endowed with bitumen and many other natural mineral resources. The State is bounded by Ekiti and Kogi States in the North, Edo and Delta States in the East, Osun and Ogun states in the West, Delta State and the Atlantic Ocean in the South. The inhabitants are majorly Yoruba speaking with some Ijaw extractions (Arogbos and Apois) in the riverine areas. The state has three senatorial districts vis. Ondo Central, North and South. Akure North LGA is one of the 18 Local Government Areas in the State with a population ${ }^{[1]}$ of 171,450. The LGA is divided into 12 administrative wards namely: Ayetoro, Igbatoro, Ilu-Abo, Isimaja, Moferere, Oba-Ile, Odo-Oja, Ogbese, Oke-Afa, Oke-Iju, Oke-Ore and Osi-Igoba.

\subsection{Study Design}

The two rural communities (Wards) under study; Ogbese and Oke-Iju were selected for their large population sizes compared to others. A systematic random sampling technique was used to identify survey houses in the selected communities. One- in- seven and one- in- -two houses were sampled in both Ogbese and Oke-Iju respectively to accommodate the population difference. The aim was to choose 280 mothers with eligible children from 280 households and 280 eligible children on the basis of 1 mother to 1 eligible child from each of the households for each ward/community. These two communities have human populations of 25,797 and 10,806 respectively. There are about 2,150 houses in Ogbese while 600 houses are in Oke-Iju. The population of children under-one year of age is about 1000 and 407 for Ogbese and Oke-Iju respectively while for under 5 , the population is 4,863 and 2,037 respectively. ${ }^{[12]}$

\subsection{Inclusion and Exclusion Criteria}

The study subjects included mother-child pairs in which the children were aged one to five years living in the selected houses in the two wards, who had been resident in the area for at least six months and had given informed consent to participate in the study. Excluded were mothers who had lived in the catchment area for less than six months and children below one year or greater than five years of age.

\subsection{Sample Size Determination}

The minimum sample size for the study was derived from a statistical formula based on the

Proportion of unimmunized children in South-West of Nigeria obtained from the 2013 National Demographic Health Survey (NDHS) ${ }^{[13]}$ The minimum sample size for study was 255 . This was however rounded up to 280 to account for $10 \%$ non-response and incomplete data. The estimated sample size of 280 was made to apply to each of the two communities, giving a total figure of 560 .

A semi-structured interviewer-administered questionnaire was used to obtain information on mothers' knowledge of vaccine preventable diseases, vaccination schedules and a historical recall of vaccines received by their children. The socio-economic status was determined using the parameters described by Ogunlesi et al. ${ }^{[14]}$

\subsection{Ethical Approval}

Ethical clearance was obtained from the Obafemi Awolowo University Research and Ethics committee. Verbal informed consent was obtained from the mothers at the point of interview.

\subsection{Data Management And Analysis}

Data collected with the questionnaires were checked for errors, entered into the computer and analyzed using STATA statistical package. The knowledge of the mothers was scored on a five-point scale for ability to name the five vaccines (OPV, BCG, DPT/Pentavalent, Measles, Yellow fever). A score of 3 and above amounts to good knowledge while 2 and below equals poor knowledge. Ability to mention any of the 10 VPDs (Tuberculosis, Polio, Diphtheria, Pertussis, Tetanus, Measles, Meningitis, Yellow fever and Pneumonia), was assessed on a scale of 1 to 10. A score of 7 and above was categorised as good knowledge; 5 to 6 as fair and 4 or less as poor. ${ }^{[10]}$ Knowledge of side effects, amelioration of the side effects and the importance of immunization were also analyzed. The relevant means and standard deviations were calculated. Confidence limit for the study was set at $95 \%$ : thus significance level was set at $\mathrm{p}<0.05$. Chi-square $\left(x^{2}\right)$ test was done as appropriate. 


\section{Results}

A total number of 560 mothers, 280 from each ward were recruited for the study. Table 1 shows the general demographic characteristics of the study subjects. Altogether $299(53.4 \%)$ respondents had male children, with a male/female ratio of 1.15:1. One hundred and forty-seven $(52.5 \%)$ of the children in Oke-Iju were males, giving a male: female ratio of $1.1: 1$ while the corresponding figures in Ogbese were $152(54.3 \%)$ males giving a male: female ratio of $1.2: 1$. The majority of the study subjects were of the Yoruba extraction (85.4\% and 63.2\% respectively for Oke-Iju and Ogbese), others were smaller ethnic groups such as Edo, Efik, Ebira and Agatu. Significantly more women in Ogbese Ward than Oke-Iju fell into the lower socio-economic class $240(85 \%)$ vs $59(21 \%)$ p $<0.05$. Majority of the families were Christians and monogamous.

Table 1: General Demographic Characteristics of the Study Subjects

\begin{tabular}{|l|l|l|l|l|}
\hline Variable & Oke-Iju (\%) & Ogbese (\%) & $X^{2}$ & p-value \\
\hline Sex of children & & & & \\
\hline Male & & & \\
\hline Female & $147(52.5)$ & $152(54.3)$ & 2.579 & 0.108 \\
\hline Age range (years) of children & $133(47.5)$ & $128(45.7)$ & & \\
\hline Under 2 years & & & & \\
\hline 2 -5 years & $128(45.7)$ & $90(32.1)$ & 10.846 & 0.001 \\
\hline Tribe & $152(54.3)$ & $190(67.9)$ & & \\
\hline Yoruba & & & & \\
\hline Hausa & $239(85.4)$ & $177(63.2)$ & 37.312 & $<0.05$ \\
\hline Igbo & $5(1.7)$ & $7(2.5)$ & & \\
\hline Others & $24(8.6)$ & $57(20.3)$ & & \\
\hline Religion & $12(4.3)$ & $39(14.0)$ & & \\
\hline Christianity & & & & \\
\hline Islam & $250(89.3)$ & $249(88.9)$ & 1.455 & 0.483 \\
\hline Traditional & $29(10.4)$ & $31(11.1)$ & & \\
\hline Family socio economic- class & $1(0.3)$ & $0(0.0)$ & & \\
\hline I & $7(2.5)$ & $1(0.4)$ & 306.865 & $<0.05$ \\
\hline II & $67(24.0)$ & $2(0.7)$ & & \\
\hline III & $147(52.5)$ & $37(13.2)$ & & \\
\hline IV & $4(1.4)$ & $187(66.7)$ & & \\
\hline V & $55(19.6)$ & $53(19.0)$ & & \\
\hline Type of family & & & & \\
\hline Single mother & $41(14.6)$ & $16(5.7)$ & 12.363 & 0.002 \\
\hline Monogamy & $211(75.4)$ & $236(84.3)$ & & \\
\hline Polygamy & $28(10.0)$ & $28(10.0)$ & & \\
\hline Others; Other ethnic & & \\
\hline
\end{tabular}

Others; other ethnic groups in Nigeria and non-Nigerians.

Tables $2 \mathrm{a}$ and $2 \mathrm{~b}$ show the socio-demographic characteristics of parents in Oke-Iju and Ogbese. About $1 \%$ of mothers in both communities were teenagers. Majority of the mothers were between the ages of 20 and 39 years $(95.7 \%$ for Oke-Iju and $95.4 \%$ for Ogbese). The mean age of mothers was $30.03 \pm 5.345$ for Oke-Iju and $28.60 \pm 5.611$ for Ogbese. The fathers were slightly older in both communities with mean ages of $35.78 \pm$ 6.168 and $34.21 \pm 6.819$ for Oke-Iju and Ogbese respectively. Parents were significantly older in Oke-Iju $(\mathrm{p}<$ $0.05)$. Majority were married and many of them attained secondary educational levels while a few had tertiary educational levels and certain percentages had no formal education $(0.4 \%$ and $2.5 \%$ for Oke-Iju and Ogbese respectively). The fathers on the other hand are majorly secondary school leavers and some of them too have tertiary level education. More than $90 \%$ of all the mothers in both communities had antenatal care in the hospitals.

Table 2a: Socio-Demographic Characteristics of Parents in Oke-Iju and Ogbese

\begin{tabular}{|l|l|l|l|l|}
\hline Variable & Oke-Iju(\%) & Ogbese $(\%)$ & $X^{2}$ & p-value \\
\hline Mother's age (yrs) & & & & \\
\hline$\leq 19$ & $3(1.1)$ & $4(1.4)$ & 9 & 0.029 \\
\hline $20-29$ & $131(46.7)$ & $163(58.3)$ & & \\
\hline $30-39$ & $137(49.0)$ & $104(37.1)$ & & \\
\hline$\geq 40$ & $9(3.2)$ & $9(3.2)$ & & \\
\hline Marital status & & & & \\
\hline Married & $274(97.8)$ & $271(96.8)$ & 0.709 & 0.702 \\
\hline Single & $5(1.8)$ & $8(2.8)$ & & \\
\hline co-habiting & $1(0.4)$ & $1(0.4)$ & & \\
\hline Maternal education & & & & \\
\hline Primary & $53(18.9)$ & $116(41.4)$ & 48.831 & $<0.05$ \\
\hline Secondary & $139(49.6)$ & $117(41.8)$ & & \\
\hline Tertiary & $87(31.1)$ & $40(14.3)$ & & \\
\hline
\end{tabular}


Mothers' Knowledge Of Immunization In Akure North Local Government...

\begin{tabular}{|l|l|l|l|l|}
\hline None & $1(0.4)$ & $7(2.5)$ & & \\
\hline Paternal education & & & & \\
\hline Primary & $37(13.2)$ & $76(27.1)$ & 30.524 & $<0.05$ \\
\hline Secondary & $130(46.5)$ & $143(51.1)$ & & \\
\hline Tertiary & $111(39.6)$ & $59(21.1)$ & & \\
\hline None & $2(0.7)$ & $2(0.7)$ & & \\
\hline Place of ANC & & & & \\
\hline None & $3(0.7)$ & $6(2.2)$ & 12.67 & $0.013^{*}$ \\
\hline Hospital & $258(92.1)$ & $255(91.2)$ & & \\
\hline Mission & $15(5.6)$ & $16(5.9)$ & & \\
\hline TBA & $4(1.6)$ & $3(0.7)$ & & \\
\hline Mother's parity & & & & \\
\hline para 1 & $70(25.0)$ & $85(30.4)$ & 24.388 & $<0.05$ \\
\hline para 2 & $90(32.1)$ & $74(26.4)$ & & \\
\hline para 3 & $53(19.0)$ & $79(28.3)$ & & \\
\hline para 4 & $50(17.8)$ & $18(6.4)$ & & \\
\hline 5 or more & $17(6.1)$ & $24(8.5)$ & & \\
\hline
\end{tabular}

Table 2b: Mean Age Of Parents In Oke-Iju And Ogbese

\begin{tabular}{|l|l|l|l|}
\hline & $\begin{array}{l}\text { Ogbese } \\
\text { Mean } \pm \text { SD }\end{array}$ & \multicolumn{1}{|l|}{-value } \\
\hline Mother's age (years) & $30.03 \pm 5.345$ & $28.60 \pm 5.611$ & 0.002 \\
\hline Father's age (years) & $35.78 \pm 6.168$ & $34.21 \pm 6.819$ & \\
& & & 0.007 \\
\hline
\end{tabular}

Table 3 shows that $100 \%$ of the respondents in Oke-Iju and $99.3 \%$ of the Ogbese respondents answered in the affirmative that they had immunized their children. When asked how many visits / immunization schedules they have had kept, $91.4 \%$ of the mothers in Oke-Iju and $90.7 \%$ of mothers in Ogbese kept the immunization schedule. Forty-seven percent of the respondents in Oke-Iju could mention the names of the vaccines and 32.5\% could not. Equal numbers of mothers in Ogbese (41.8\%) were observed to either mention the names of the vaccines or not. In terms of the diseases the vaccines prevent; the respondents in both communities were more familiar with the Polio vaccines, followed by Measles and the respondents had the least knowledge of the diseases preventable by DPT / Pentavalent vaccine prevents (Table 4a, 4b, Fig. 1 and 2).

Sixty-one percent of the respondents in Oke-Iju and $63.2 \%$ in Ogbese said their children sometimes experience side effects after immunization such as fever (about $70 \%$ for both communities), rashes; $25(8.9 \%$ ) for Oke-Iju and 20 (7.2\%) for Ogbese) and convulsion 8 (2.9\%) for Oke-Iju and 2 (0.7\%) for Ogbese), swelling at immunization site; $55(19.6 \%)$ for Iju and $60(21.5 \%)$ for Ogbese), watery stools; $33(11.8 \%)$ for Oke-Iju and 28 ( $10 \%)$ for Ogbese), excessive cry; 109 (40\%) in Oke-Iju and 81 (29\%) in Ogbese). A significantly higher number of women in Ogbese however said weakness was not part of the side effects manifested by children (pvalue $=0.002$ )

To ameliorate these side effects, majority of the respondents $(51.5 \%$ for Oke-Iju and $64.2 \%$ for Ogbese) treated their children with paracetamol. Significantly more mothers used parecetamol in Ogbese than Oke-Iju (p-value $=0.004)$. Other measures were cold birth before taking child back to the hospital. Concerning the question; "why do you immunize your child?" Majority of the mothers; 277 (98.9\%) for Oke-Iju and 279 (99.7\%) for Ogbese said immunization protects children against infections.

Table 5 shows the multivariate analysis between mothers' knowledge of immunization and associated variables. Statistically in Oke-Iju, mothers of children in the upper socio-economic class were 2.6 times more likely to have good knowledge of immunization than those in low socio-economic class. ( $p=0.039$; CI 1.0486.391). Also, respondents whose source of information was through antenatal clinic / health workers were 2.3 times more likely to have good knowledge of immunization than those from other sources of information (pvalue 0.003; CI 1.321-3.907) and mothers whose place of antenatal care was non-hospital were 2 times less likely to have a good knowledge of immunization than mothers with hospital based antenatal care (p-value 0.029; CI 0.054-0.854) while in Ogbese, multigravida mothers were 3.2 times more likely to have good knowledge of immunization than Primigravida mothers (p-value 0.002; CI 1.528-6.864). 
Table 3: Mothers Knowledge Of Immunization In Oke-Iju And Ogbese Towns

\begin{tabular}{|c|c|c|c|c|c|c|}
\hline & \multicolumn{2}{|c|}{ Oke-Iju town } & \multicolumn{2}{|c|}{ Ogbese town } & \multirow[b]{2}{*}{$\begin{array}{l}\mathrm{p} \\
\text { value }\end{array}$} & \\
\hline Variable & $\begin{array}{l}\text { Frequency } \\
(\mathrm{n}=280)\end{array}$ & $\begin{array}{l}\text { Percentage } \\
(\%)\end{array}$ & $\begin{array}{l}\text { Frequency } \\
(\mathrm{n}=280)\end{array}$ & $\begin{array}{l}\text { Percentag } \\
(\%)\end{array}$ & & \\
\hline \multicolumn{6}{|l|}{$\begin{array}{l}\text { Have you immunized } \\
\text { this child? }\end{array}$} & \\
\hline Yes & 280 & 100 & 278 & 99.3 & \multirow[t]{2}{*}{0.093} & \\
\hline No & 0 & 0.0 & 2 & 0.7 & & \\
\hline \multicolumn{6}{|l|}{$\begin{array}{l}\text { Do the children } \\
\text { sometimes experience } \\
\text { side effects? }\end{array}$} & \\
\hline Yes & 172 & 61.4 & 177 & 63.2 & \multirow[t]{2}{*}{0.663} & \\
\hline No & 108 & 38.6 & 103 & 36.8 & & \\
\hline \multicolumn{6}{|l|}{$\begin{array}{l}\text { Why do we immunize } \\
\text { children? }\end{array}$} & \\
\hline protect against disease & 246 & 87.6 & 231 & 82.5 & \multirow[t]{3}{*}{0.092} & \\
\hline Prevention & 31 & 11.3 & 48 & 17.2 & & \\
\hline $\begin{array}{l}\text { Confers some } \\
\text { advantages }\end{array}$ & 3 & 1.1 & 1 & 0.3 & & \\
\hline \multicolumn{6}{|l|}{$\begin{array}{l}\text { Fever as a side effect of } \\
\text { immunization }\end{array}$} & \\
\hline Yes & 197 & 70.4 & 197 & 70.6 & \multirow[t]{2}{*}{0.948} & \\
\hline No & 83 & 29.6 & 83 & 29.4 & & \\
\hline \multicolumn{6}{|l|}{$\begin{array}{l}\text { Rashes as side effect of } \\
\text { immunization }\end{array}$} & \\
\hline Yes & 25 & 8.9 & 20 & 7.2 & \multirow{2}{*}{0.444} & \\
\hline No & 255 & 91.1 & 260 & 92.8 & & \\
\hline \multicolumn{6}{|l|}{$\begin{array}{l}\text { Convulsion as a side } \\
\text { effect of immunization }\end{array}$} & \\
\hline Yes & 8 & 2.9 & 2 & 0.7 & \multirow{2}{*}{0.626} & \\
\hline No & 272 & 97.1 & 278 & 99.3 & & \\
\hline \multicolumn{6}{|l|}{$\begin{array}{l}\text { Weakness as a side } \\
\text { effect of immunization }\end{array}$} & \\
\hline Yes & 80 & 28.6 & 49 & 17.6 & \multirow[t]{2}{*}{0.002} & \\
\hline No & 200 & 71.4 & 231 & 82.4 & & \\
\hline \multicolumn{6}{|l|}{$\begin{array}{l}\text { Swelling as a side effect } \\
\text { of immunization }\end{array}$} & \\
\hline Yes & 55 & 19.6 & 60 & 21.5 & \multirow[t]{2}{*}{0.586} & \\
\hline No & 225 & 80.4 & 220 & 78.5 & & \\
\hline \multicolumn{7}{|l|}{$\begin{array}{l}\text { Watery stool as a side } \\
\text { effect of immunization }\end{array}$} \\
\hline Yes & 33 & & 11.8 & 28 & 10 & \multirow[t]{2}{*}{0.498} \\
\hline No & 247 & & 88.2 & 252 & 90 & \\
\hline \multicolumn{7}{|l|}{$\begin{array}{l}\text { Excessive cry as a side } \\
\text { effect of immunization }\end{array}$} \\
\hline Yes & 109 & & 38.9 & 81 & 29 & 0.014 \\
\hline No & 171 & & 61.1 & 198 & 71 & \\
\hline $\begin{array}{l}\text { What do you do to } \\
\text { relieve side effects? }\end{array}$ & & & & & & \\
\hline Cold bath & 80 & & 28.5 & 47 & 16.7 & 0.004 \\
\hline Paracetamol & 150 & & 53.6 & 182 & 65.0 & \\
\hline Take baby to hospital & 48 & & 17.1 & 50 & 17.9 & \\
\hline Others & 2 & & 0.7 & 1 & 0.4 & \\
\hline $\begin{array}{l}\text { Why do you think } \\
\text { immunization is } \\
\text { necessary? }\end{array}$ & & & & & & \\
\hline Cheap/free & 8 & & 2.9 & 2 & 0.7 & $<0.05$ \\
\hline For its benefit & 66 & & 23.6 & 33 & 11.7 & \\
\hline Mandatory & 6 & & 2.2 & 15 & 5.4 & \\
\hline $\begin{array}{l}\text { For school and daycare } \\
\text { placement }\end{array}$ & 2 & & 0.7 & 5 & 1.8 & \\
\hline Protect against diseases & 198 & & 70.6 & 225 & 80.4 & \\
\hline $\begin{array}{l}\text { How many } \\
\text { immunization visits/ } \\
\text { schedule did you keep? }\end{array}$ & & & & & & \\
\hline All & 256 & & 91.4 & 254 & 90.7 & 0.767 \\
\hline Missed some & 24 & & 8.6 & 26 & 9.3 & \\
\hline
\end{tabular}

Others : use of herbs, take no action 
Mothers' Knowledge Of Immunization In Akure North Local Government...

Table 3a: Ability of Respondents to Name the Five Vaccines

\begin{tabular}{|c|c|c|l|c|c|c|}
\hline & \multicolumn{2}{|l|}{ Oke-Iju town } & \multicolumn{2}{l|}{$\begin{array}{c}\text { Ogbese town } \\
\text { value }\end{array}$} \\
\hline Variable & $\begin{array}{l}\text { Frequency } \\
(\mathrm{n}=280)\end{array}$ & Percentage (\%) & $\begin{array}{l}\text { Frequency } \\
(\mathrm{n}=280)\end{array}$ & Percentage (\%) & & \\
\hline $\begin{array}{c}\text { Good } \\
\text { knowledge }\end{array}$ & 131 & 46.8 & 117 & 41.8 & & \\
\hline Fair knowledge & 58 & 20.7 & 46 & 16.4 & 5.42 & 0.066 \\
\hline Poor knowledge & 91 & 32.5 & 117 & 41.8 & & \\
\hline
\end{tabular}

Table 4b: Immunization Prevents The Following Diseases

\begin{tabular}{|c|c|c|c|c|}
\hline & \multicolumn{2}{|l|}{ Oke-Iju town } & \multicolumn{2}{|l|}{ Ogbese town } \\
\hline Variable & Frequency $(n=280)$ & Percentage (\%) & Frequency $(n=280)$ & Percentage (\%) \\
\hline \multicolumn{5}{|l|}{ Diphtheria } \\
\hline Agree & 165 & 58.87 & 138 & 49.36 \\
\hline Disagree & 17 & 6.05 & 13 & 4.68 \\
\hline Don't know & 98 & 35.08 & 129 & 45.96 \\
\hline \multicolumn{5}{|l|}{ Pertussis } \\
\hline Agree & 172 & 61.36 & 132 & 47.06 \\
\hline Disagree & 11 & 3.98 & 13 & 4.62 \\
\hline Don't know & 97 & 34.66 & 135 & 48.32 \\
\hline \multicolumn{5}{|l|}{ Tetanus } \\
\hline Agree & 267 & 95.27 & 249 & 88.93 \\
\hline Disagree & 2 & 0.73 & 31 & 11.07 \\
\hline Don't know & 11 & 4.00 & 0 & 0 \\
\hline \multicolumn{5}{|l|}{ Tuberculosis } \\
\hline Agree & 273 & 97.47 & 246 & 89.13 \\
\hline Disagree & 1 & 0.36 & 7 & 2.54 \\
\hline Don't know & 6 & 2.17 & 23 & 8.33 \\
\hline \multicolumn{5}{|l|}{ Polio } \\
\hline Agree & 276 & 98.57 & 256 & 91.58 \\
\hline Disagree & 0 & 0 & 8 & 2.93 \\
\hline Don't know & 4 & 1.43 & 16 & 5.49 \\
\hline \multicolumn{5}{|l|}{ Measles } \\
\hline Agree & 273 & 97.50 & 260 & 93.19 \\
\hline Disagree & 0 & 0 & 2 & 0.72 \\
\hline Don't know & 7 & 2.50 & 18 & 6.09 \\
\hline \multicolumn{5}{|l|}{ Meningitis } \\
\hline Agree & 211 & 75.48 & 179 & 63.79 \\
\hline Disagree & 4 & 1.53 & 8 & 2.88 \\
\hline Don't know & 65 & 22.99 & 93 & 33.33 \\
\hline \multicolumn{5}{|l|}{ Yellow fever } \\
\hline Agree & 272 & 97.13 & 258 & 92.00 \\
\hline Disagree & 1 & 0.36 & 3 & 1.09 \\
\hline Don't know & 7 & 2.51 & 19 & 6.91 \\
\hline \multicolumn{5}{|l|}{ Pneumonia } \\
\hline Agree & 221 & 78.97 & 191 & 68.05 \\
\hline Disagree & 6 & 2.21 & 7 & 2.63 \\
\hline Don't know & 53 & 18.82 & 82 & 29.32 \\
\hline \multicolumn{5}{|l|}{ Hepatitis } \\
\hline Agree & 196 & 70.00 & 155 & 55.26 \\
\hline Disagree & 7 & 2.61 & 13 & 4.82 \\
\hline Don't agree & 77 & 27.39 & 112 & 39.92 \\
\hline
\end{tabular}

Figure 1: Respondents knowledge on the number of vaccines in pentavalent vaccine; $20.7 \%$ and $7.9 \%$ respectively in Oke-Iju and Ogbese said there are five vaccines in the pentavalent vaccines.

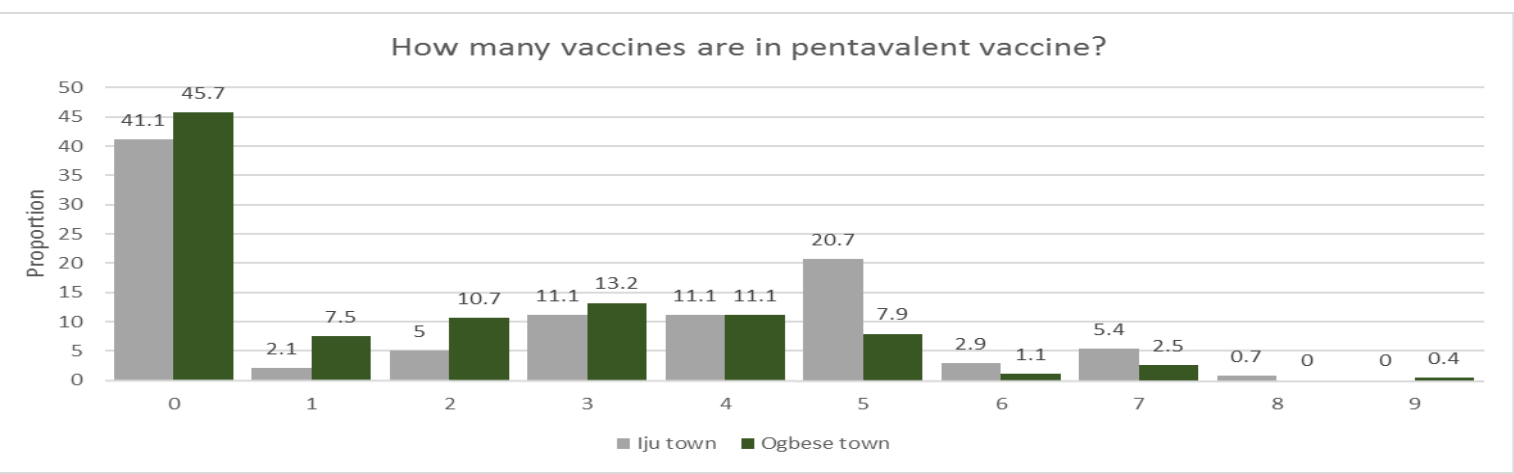


Figure 2: Knowledge of side effects of pentavalent vaccine.

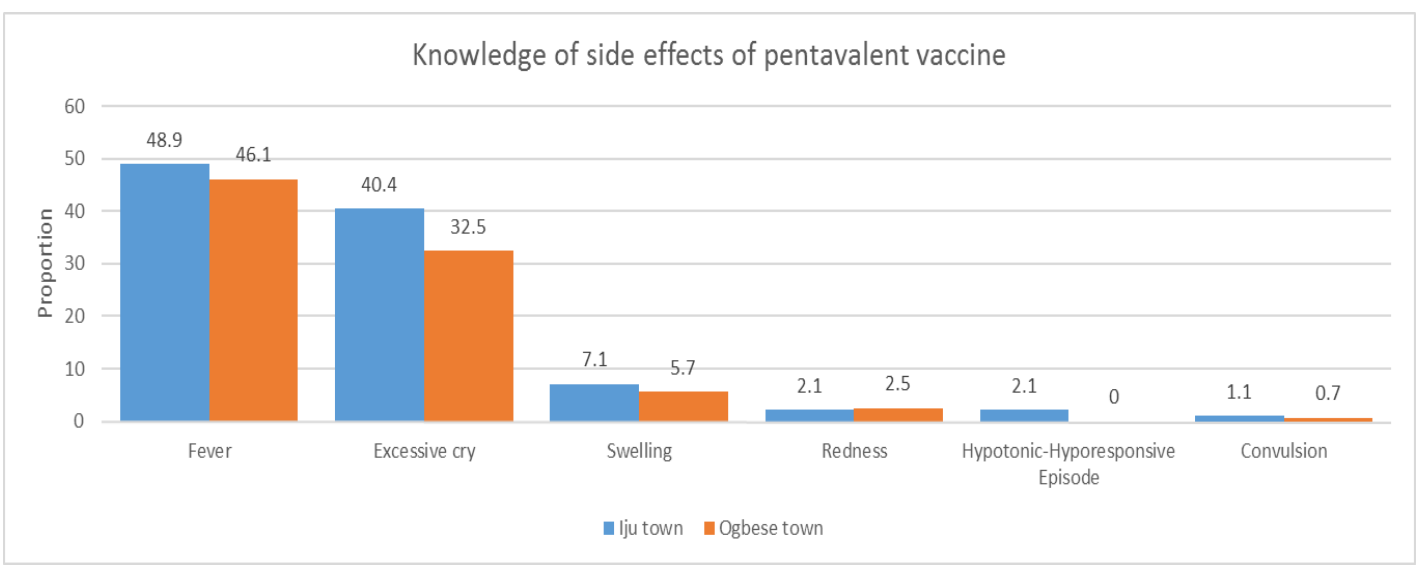

Table 5: Multivariate Analysis between Knowledge of Immunization and Associated Variables

\begin{tabular}{|l|l|l|l|l|l|l|}
\hline \multicolumn{2}{l}{} & \multicolumn{2}{l}{ Iju town } & & \multicolumn{3}{l|}{ Ogbese town } & \\
\hline Variable & OR & CI & P-Value & OR & CI & P-Value \\
\hline Mother's parity & & & & & & \\
\hline Primigravida & 1 & & & 1 & & \\
\hline Multigravida & 1.5 & $0.789-2.939$ & 0.214 & 3.2 & $1.528-6.864$ & 0.002 \\
\hline Grand multi gravid & 0.4 & $0.079-1.592$ & 0.176 & 0.5 & $0.139-2.136$ & 0.384 \\
\hline Child socio economic class & & & & & & \\
\hline Low & 1 & & & 1 & & \\
\hline Middle & 1.4 & $0.714-2.939$ & 0.304 & 1.5 & $0.520-4.509$ & 0.439 \\
\hline Upper & 2.6 & $1.048-6.391$ & 0.039 & 0.6 & $0.034-14.059$ & 0.812 \\
\hline Source of information & & & & & & \\
\hline Others* & 1 & & & 1 & & \\
\hline Antenatal & 2.3 & $1.321-3.907$ & 0.003 & 0.9 & $0.494-1.844$ & 0.891 \\
\hline Place of ANC & & & & & & \\
\hline Non-hospital & 1 & & & 1 & & 0.029 \\
\hline Hospital & 1.9 & $0.674-5.131$ & 0.23 & 0.2 & $0.054-0.854$ & 0.2 \\
\hline
\end{tabular}

*Radio/TV, Friend, non-health workers

\section{Discussion}

In the current study, the mothers' knowledge of immunization is high however significant differences exist between communities. This higher level of knowledge may be attributable to the high community mobilization and the quality of information provided to mothers at the health facilities. The respondents in the age group 20 to 39 years also had better knowledge compared to others, this may be attributed to the fact that they are still young and attentive rather than the older women who have "wrong" confidence in themselves and are not readily malleable or teachable due to their "experience." This is similar to findings in the Karachi study where they reported that 'Years since marriage' which also served as a proxy for the age of the mother and level of education was inversely proportional to mothers' knowledge and immunization coverage. ${ }^{[10]}$

Married mothers and those of the Yoruba extraction were more likely to have better knowledge of immunization than the other tribes and the unmarried ones in both communities, this is similar to the finding at the National level ${ }^{[13]}$ where majority $(71 \%)$ of the female respondents are married and living together with their partners. The universality of marriage in Nigeria is said to probably reflect the social and economic security marriage is perceived to provide ${ }^{[13]}$ which will in turn reflect positively on the health of the people.

In Oke-Iju, mothers of children in the upper socio-economic class were 2.6 times more likely to have good knowledge of immunization than those in the low socio-economic class. This finding is in agreement with the Karachi study ${ }^{[10]}$ where most $(80 \%)$ of the respondents were low income earners, had less than 10 years of schooling and were un-employed (94.3\% were house-wives) and had less knowledge. The reason adduced to this at the national level has to do with the fact that education and wealth quintiles are two important determinants of an individual's attitude and outcome on various aspect of life. ${ }^{[13]}$ The educational level of an individual, level of exposure, knowledge, power to make wealth and the socio-economic status are closely interrelated. In the various zones of Nigeria, ${ }^{[13]}$ North-West and North-East have the highest proportion of women with no education (69\% and 64\% respectively), the South-East and South-South have the lowest (5\% each) and the South-West is $8.4 \%$ (Ondo state being 7.5\%). Generally, $87.2 \%$ of Nigerians with secondary or higher level of education are in the highest wealth quintile in the nation. ${ }^{[13]}$ In the current study, only a small number of 
parents did not have formal education hence the higher level of immunization knowledge especially among Oke-Iju mothers and those who attended antenatal clinics and got information from the hospital / health workers where majority of these health information emanate from. The implication for Ogbese is that policy makers need to focus and work more on the people to get them informed, educated and to participate in programs that are beneficial to their wellbeing and also to keep up the already achieved milestone in the health sector. This research also provides evidence for the need to launch an adequate health education strategy that targets women regularly everywhere they are, in order to reinforce their knowledge, awareness and to tell them about the usefulness of immunization in terms of being a cost-effective means of preventing deaths from the VPDs.

Knowledge of immunization generally is high in the current study. Despite the fact that greater than 90 $\%$ of the women in both communities had antenatal care in the hospitals and got their information from same source, a greater proportion (74\%) of mothers in both communities also had more than one child ( $\geq$ para 2$)$, and by implication would have listened to the immunization health talk more than once. Less than $50 \%$ of the women in both communities could mention the names of the vaccines. They also could not tell how many 'antigens' or vaccines there are in the pentavalent vaccine. However, they had good understanding of what the vaccines were meant for (to prevent diseases), they knew some of the side effects, they knew what to do if side effects arose and they kept their immunization schedule. However, Oke-Iju was slightly higher in knowledge than Ogbese. The question then arises about how attentive these women are in the clinics or how capable the immunization staff who pass the information to them are. The knowledge gap observed between Oke-Iju and Ogbese communities under review can be attributed to the fact that Oke-Iju has more of middle class mothers, though also rural but it has better community mobilization and participation for immunization. Ogbese on the other hand, has more mothers in the low socio-economic class. It is a rural community but the small town is a commercial centre along a major express road linking the South-West to the South-South with a lot of street trading and so more pre-occupied with business activities. The implication here is that policy makers should find a means to reach out to this community at a more convenient period for them to educate them and encourage them to participate more and get fully involved in programs that would benefit them.

The proportion of mothers who have good knowledge in the current study is comparable to figures obtained elsewhere in Jos, ${ }^{[15]}$ Enugu ${ }^{[1], ~[~ 7]}$ and Oshogbo ${ }^{[16]}$ and higher than figures from Ibadan ${ }^{[17]}$ and Ifewara. ${ }^{[16]}$ Though Jos and Oshogbo are more cosmopolitan with higher levels of exposure than the communities under review. Ibadan and Ifewara on the other hand are ancient city / village with more slums and less exposed inhabitants.

The current study revealed that the higher the level of education, the higher the knowledge of immunization. This has also been earlier reported in Nigeria by Sadoh et al ${ }^{[18]}$ and Odusanya et al ${ }^{[19]}$ and corroborated by several other studies from Libya, ${ }^{[8]}$ Pakistan ${ }^{[10]}$ and Europe. ${ }^{[20]}$ However, studies from Enugu have reported that there is no association between knowledge of immunization and level of education. ${ }^{[1]}$, [7] These studies have related the knowledge of immunization to level of exposure, community mobilization, commitment of the medical staff and the family physician. Our study also revealed that mothers' knowledge is high and accurate. More than $98 \%$ of the mothers in both communities agreed that the vaccines all together protect the children from 'diseases,' the mothers however know more about Polio vaccines, followed by the measles and showed the least knowledge of DPT/ pentavalent vaccines. Some Asian and African countries on the other hand have reported poor and wrong knowledge of immunization. ${ }^{[21]}$ Investigators in Gadap (Karachi $)^{[10]}$ reported that the assessment of the knowledge of the infants' mothers about Expanded Programme on Immunization revealed serious deficiencies. On a scale of $1-11$, the mean knowledge score was $3.8 \pm 3.3$, with only about 2 percent of the mothers scoring the maximum possible and almost one quarter of the mothers scored zero. ${ }^{[17]}$ In the current study, though no mother scored zero, only $20.1 \%$ of the mothers in Oke-Iju and $7.9 \%$ in Ogbese knew that the pentavalent vaccine contain and prevent five diseases. The implication is that mothers in this part of the country should continually be educated, updated, mobilized and encouraged to pay attention to teachings, lectures, demonstrations when they attend clinics as well as improve upon their efforts geared towards acquiring immunization knowledge with emphasis on the fact that immunization is the most cost-effective means of reducing morbidity, mortality and disability among children.

\section{Conclusions}

The current study revealed that the general knowledge of immunization is high in Akure North Local Government Area of Ondo State. The study also revealed that the higher the level of education, the higher the mothers' knowledge of immunization but significant differences exist between both communities and so interventions to improve and sustain immunization health literacy should be instituted. 


\section{References}

[1]. B.N Tagbo, N.D Uleanya, I.C Nwokoye, J.C Eze and I.B Omotowo. Mothers' knowledge, perception and practice of childhood immunization in Enugu. Niger J paed 2012; 39(3) : 90-96. DOI:http://dx.doi.org/10.4314/njp.v39i3.1

[2]. Edna Iroha, Vaccines and Immunization, in Azubuike JC, Nkaginieme KEO (editors), Paediatrics and Child Health in a tropical region $2^{\text {nd }}$ ed. (African Educational Services, Nigeria, 2007) Pg. 28-30.

[3]. World Health Organization, (2008). Immunization profile in Nigeria. [Accessed Jan 3 2016]; [7 screens] Available from: http://www.who.int/vaccines/globalsummary/ immunization/country profile result. cfm?C='nga'.

[4]. O. Aetekah , H. Beenis, R.S Amna, A. Ajmal and K.M Anita. Does improving maternal knowledge of vaccines impact on Immunization rates? A randomized-controlled trial in Karachi, Pakistan. BMC Public Health 2011;11:239 Available at: http://ecommons.aku.edu/pakistan_fhs_mc_women_childhealth_paediatr/66

[5]. A. Oyo-Ita, B, Fakunle, A. Fajola and E. Edet. Immunization Coverage in Selected Communities in the Niger Delta, Nigeria. World Journal of Vaccines, 2012, 2, 21-26 http://dx.doi.org/10.4236/wjv.2012.21003.

[6]. O. Qutaiba B Al-lela, M.B Bahari, H.K Al-Qazaz, R.M Salih, S.Q Jamshed and R.M Elkalmi. Are parents' knowledge and practice regarding immunization related to pediatrics' immunization compliance? a mixed method study. BMC Pediatr. 2014; 14: 20. Published online 2014 Jan 25. doi: 10.1186/1471-2431-14-20.

[7]. B.N Tagbo, N.D Uleanya and I.B Omotowo. Mothers' Knowledge and Perception of Adverse Events Following Immunization in Enugu, South East,Nigeria . J Vaccines Vaccin 2013;4:6. http://dx.doi.org/10.4172/2157-7560.1000202.

[8]. A.M Mabrouka. Knowledge, attitude and practices of mothers regarding immunization of infants and preschool children at AlBeida City, Libya. Egypt J Pediatr Allergy Immunol 2011;9(1):29-34.

[9]. J.Jisi, M.R Lobo, K. Nisha , G.S Shilpa and J. Umarani. Awareness On Immunization Among Mothers Of Underfive Children. INTERNATIONAL JOURNAL OF INNOVATIVE RESEARCH \& DEVELOPMENT 2013;6: 620-6. www.ijird.com June, 2013 Vol 2 Issue 6.

[10]. N.A Azfar-e-Alam Siddiqi, N. Nighat and K. Altaf. Mothers knowledge about EPI and its relation with age-appropriate vaccination of infants in peri-urban Karachi. JPMA 2010;60:940.

[11]. National Population Commission. 2006 Provisional Census Results. Federal Republic of Nigeria official Gazette 2007;94:24.

[12]. Routine Immunization Performance. Ondo State Pry Healthcare Board Data on Ondo State Target Population by wards (2013 estimates).

[13]. National Demographic and Health Survey (NDHS) 2013. [Accessed 11/2/16]; [566 screens]: Available at http://www.neuroaro.com/sites/default/files/downloadables/Nigeria\%20DHS\%202013\%20Full\%20Report.pdf .

[14]. T.A Ogunlesi, I.O.F Dedeke and O.T Kuponiyi. Socio-Economic Classification of Children attending Specialist Paediatric Centres in Ogun State, Nigeria. Nigerian Medical Practitioner 2008;54 (1):21-25.

[15]. G.O Chris-Otubor, D.A Dangiwa , L.D Ior and N.C Anukam. Assessment of Knowledge, Attitudes and Practices of Mothers in Jos North Regarding Immunization. IOSR Journal Of Pharmacy.2015;6:34-45. Available from www.iosrphr.org

[16]. P.O Obiajunwa and A.A Olaogun. Childhood Immunization Coverage in South West Nigeria. Sudanese Journal of public health (SJPH 2013;8 (3):92-96). www.sjph.net.sd/files/Vol8N3/Original_Article2.pdf [accessed 4th April 2016, 4 screens]

[17]. M.K Omole and K.O Owodunni. Mothers' Knowledge of Immunization Programme and Factors Influencing Their Compliance at a Children Hospital in South West Nigeria. JOURNAL OF PHARMACEUTICAL AND BIOMEDICAL SCIENCES (Available online at www.jpbms.info) . JPBMS 2012; 21:1-4

[18]. A.E Sadoh and C.O Eregie. Timeliness and completion rate of immunization among Nigerian children attending a clinic-based immunization service. J Health Popul Nutr. 2009;27(3):391-395. [PMC free article][PubMed]

[19]. O.O Odusanya, E.F Alufohai, P.F Meurice. and V.I Ahonkhai. Determinants of vaccination coverage in rural Nigeria. BMC Public Health 2008; 8: 381. Available from: http://www.ncbi.nlm.nih.gov/pmc/articles/PMC2587468/

[20]. World Health Organization (2005). Pocket Book of Hospital Care for Children. [Accessed 16 ${ }^{\text {th }}$ March, 2016]; [2 screens]. Available from: http://www.who.int/maternal_child_adolescent/documents/9241546700/en/index.html

[21]. M. Jheeta and J. Newell. Childhood vaccination in Africa and Asia: the effects of parents' knowledge and attitudes. Bull World Health Organ. 2008 ; 86:419. doi: 10.2471/BLT.07.047159 